


\title{
AGRONOMIC AND MORPHOLOGICAL CHARACTERISTICS OF QUINOA GROWN IN THE SOUTHERN REGION OF RIO GRANDE DO SUL STATE
}

VERGARA, R. O.; MARTINS, A. B. N.; SOARES, V. N.; CARVALHO, I. R,; BARBOSA, M. H.; CONTE, G.G.; GADOTTI, G. I.; LUDTKE,

R.; VILLELA, F. A.

Keywords: Chenopodium quinoa; yield estimation; varietal mixture; seed production.

\begin{abstract}
The objective of the present study was to describe the morphological characteristics that allow the differentiation of cultivars and to evaluate the agronomic characteristics that can determine the yield of Chenopodium quinoa cultivated in the southern part of Rio Grande do Sul. Quinoa is a pseudocereal that it is originally from the Andes region; it is consumed throughout the world due to its nutritional characteristics. Its introduction and production in Brazil are recent, so studies that make possible the increase of growing are of great importance. We evaluated the stem, leaf and inflorescence characteristics, number of seeds per branch, number of branches and mass of one thousand seeds, thus obtaining the agronomic characteristics. We calculated the yield of the cultivars using the adjusted formula for estimated yield. It was observed that the characteristics of the leaf could be used to differentiate the cultivars. It is possible to calculate the yield of the crop using the adjusted formula for estimated yield. For the culture of quinoa it is possible to use morphological genetic markers with the conformations of the teeth or lobes of the leaf and its shade, in contrast, the length of the petioles are not good markers due to low genetic variability. The genetic and phenotypic variability and trends expressed in this study allow further studies of genetic improvement, seed technology and agronomic positioning for quinoa to be carried out for other regions of Brazil.
\end{abstract}

\section{CARACTERÍSTICAS AGRONÔMICAS E MORFOLÓGICAS DA QUINOA CULTIVADA NA REGIÃO SUL DO RIO GRANDE DO SUL}

Palavras-chave: Chenopodium quinoa; estimativa de rendimento; mistura varietal; produção de sementes.

\section{Resumo}

O objetivo do presente estudo foi descrever as características morfológicas que permitem a diferenciação de cultivares e avaliar as características agronômicas que podem determinar o rendimento de Chenopodium quinoa cultivada na parte sul do Rio Grande do Sul. Foram avaliadas as características do caule, folha e inflorescência, número de sementes por galho, número de galhos e massa de mil sementes, obtendo as características agronômicas. Calculamos o rendimento das cultivares usando a fórmula ajustada para o rendimento estimado. Observou-se o número de dentes ou lóbulos da folha poderiam ser utilizadas para auxiliar na diferenciação das cultivares. É possível calcular o rendimento da colheita usando a fórmula ajustada para o rendimento estimado. Para a cultura da quinoa é possível utilizar marcadores genéticos morfológicos com as conformações dos dentes ou lóbulos da folha e sua tonalidade, em contrapartida, o comprimento dos peciólos são bons marcadores devido à baixa variabilidade genética. A variabilidade genética e fenotípica e as tendências expressas neste estudo permitem que novos estudos de melhoramento genético, tecnologia de sementes e posicionamento agronômico para quinoa sejam realizados para outras regiões do Brasil. 


\section{INTRODUCTION}

Quinoa (Chenopodium quinoa Willd) is an annual plant belonging to the Amaranthaceae family (FuentesBazan et al., 2012), and was domesticated thousands of years ago by the native people of the Andes Mountain Range (Spehar \& Santos, 2002). Although it does not belong to the same botanical family, quinoa is often referred to as a "pseudocereal" due to its similarity to the organic-mineral composition of cereals.

The Amaranthaceae family includes about 170 genera and approximately 2000 species, distributed throughout the globe except for the cold regions of the Northern Hemisphere, being preferentially found in altered, arid or saline environments (Judd et al., 2009; Souza \& Lorenzi, 2012). The genus Chenopodium includes annual or perennial plants that are herbaceous and sub-shrubs, glabrous or hairy, with leaves simple and petiolate with alternating spiral phyllotaxis. The flowers are incomplete, with 3-5 sepals, usually five stamens free or very rarely united by the filaments and united to the chalice, forming a small disk. The ovary is superimposed, tricarpellar, unilocular, with a short stylet and bifid stigma, capped to elongated. The fruit is of the nucula type, unisseminated, surrounded by a persistent chalice. The pericarp is thin, membranous and adhered to the seminal integument. The embryo is curved and annular (Burkart, 1987; Barroso et al., 1999).

For genetic variability to be efficiently used it must be correctly evaluated and quantified. The description of any introductions and accessions for the maintenance and exploitation of a collection's potential is essential. Such characterization can be done using molecular markers or morphological or molecular descriptors (Singh, 2001).

The morphophysiological characteristics, such as the number of branches per plant, length of branches and number of fertile nodes, are related to the productive potential of the plant since they represent an additional photosynthetic and potentially productive surface by determining the number of places for flower emergence (Navarro Júnior \& Costa, 2002).

Knowledge of the responses of the plant yield components, the availability of photoassimilates, and the identification of the point at which these components are formed is important in the selection of characteristics to be incorporated into cultivars. In this context, the analysis of agronomic characters is one of the methods used to understand the factors involved in the associations between characters and thus to decompose the correlation between direct and indirect effects and the main variable, such as grain yield, and explanatory variables, that is, the income components (Zilio et al., 2011). The objective of the present study was to evaluate the morphological characteristics that make it possible to differentiate cultivars and the agronomic characters that determine the yield of C. quinoa grown in the southern part of Rio Grande do Sul State.

\section{MATERIAL AND METHODS}

Trials were conducted in the experimental field of Embrapa Clima Temperado (Pelotas-RS), on upland soils. We used seeds of cultivar BRS Piabiru and cultivars named 1 and 2. Seeds were sown in October 2015 , at a distance between rows of $0.40 \mathrm{~m}$ and sowing depth of $0.02 \mathrm{~m}$, giving a population of 400,000 plants per hectare. For each cultivar, three blocks 1.2 $\mathrm{m}$ in width and $6 \mathrm{~m}$ in length were used. Only the central row of the block was collected, so the lateral rows were used as a border. Soil samples were collected for analysis to guide fertilization, adopting the criteria established by Spehar (2006), and based on nutrient export data for an estimated grain yield of 2.5 t.ha- ${ }^{1}$ $(50 \mathrm{~kg}$ of N, $6 \mathrm{~kg}$ of P, $80 \mathrm{~kg}$ of K, $33 \mathrm{~kg}$ of Ca, $20 \mathrm{~kg}$ of $\mathrm{Mg}, 0.6 \mathrm{~kg}$ of Fe, $0.2 \mathrm{~kg}$ of $\mathrm{Mn}$ and $0.07 \mathrm{~kg}$ of $\mathrm{Zn}$ ).

Plants were collected in the morning and taken to the Didactic Laboratory of Seed Analysis of the Postgraduate Program in Seed Science and Technology, Universidade Federal de Pelotas. Ten replicates from each block were collected to evaluate the agronomic characteristics, each replicate consisting of two plants, totaling 30 experimental units. Branching number, number of seeds per branch, and the mass of one thousand seeds per plant were evaluated, the last two variables expressed in grams, the cycle was the 90 days.

The yield of soybean can be related to the number of pods per plant, the number of grains per pod, the mass of one thousand seeds and the number of plants per area (Thomas \& Costa, 2010). Thus, it is possible to obtain an adjusted formula for other crops by considering the 
characteristics of the crop. Thus, for quinoa, we must consider the number of branches, number of seeds per branch, the mass of one thousand seeds and number of plants per unit area. The following equation was used: Production per plant $=\mathrm{N}^{\circ} \mathrm{B} * \mathrm{~N}^{\circ} \mathrm{SB}^{*}(\mathrm{MTS} / 1000)$ ${ }^{*} \mathrm{~N}^{\circ} \mathrm{PL} /$ area, Where: $\mathrm{N}^{\circ} \mathrm{B}=$ number of branches, $\mathrm{N}^{\circ} \mathrm{SB}=$ number of seeds per branch, MTS= mass of a thousand seeds, $\mathrm{N}^{\circ} \mathrm{PL} / \mathrm{area}=$ population of plants per unit area.

\section{Statistical procedure}

The data were submitted to analysis of variance and if significant were compared using the Tukey test with a level of 5\% significance. For validation of the adjusted equation used to estimate the yield of the culture, the Chi-square test was used. For the morphological description the following morphological characters were observed: growth habit, shape, stem diameter and pigmentation, presence or not of pigmented armpits, presence or not and stem streak pigmentation, presence and number of branches, position of branches, shape of stem, leaf size, number of teeth on leaf margin, length and color of petiole, leaf size and color, presence or absence and color of leaf granules, color of panicle at flowering, panicle shape, and length and panicle diameter, according to FAO, PROINPA, INIAF, and FIDA (2013).

\section{RESULTS AND DISCUSSION}

Morphological differences regarding agronomic characters were observed between cultivars (Table 1). Cultivars 1 and 2 had more branches than BRS Piabiru. The number of seeds per branch also differed between cultivars, with BRS Piabiru and cultivar 1 producing a larger number of seeds per branch than cultivar 2 . Cultivar 1 produced a larger number of seeds per plant than BRS Piabiru. BRS Piabiru and cultivar 1 had the highest mass of one thousand seeds. The production of seeds per plant varied between cultivars (Table 1). Cultivar 1 produced the most seeds, followed by BRS Piabiru and cultivar 2. Seed production per plant of cultivar 1 was $59 \%$ higher than in BRS Piabiru.

Table 1. Agronomic characters of three quinoa cultivars grown in the Southern region of Rio Grande do Sul.

\begin{tabular}{cccccc}
\hline Cultivar & Number of branches & Number of seeds per branch & Number of seeds per plant & Thousand seeds mass (g) & Production (g.plant- $\left.{ }^{1}\right)$ \\
\hline BRS Piabiru & $35,56 \mathrm{~b}$ & $155,44 \mathrm{a}$ & $5522 \mathrm{~b}$ & $1,92 \mathrm{a}$ & $10,58 \mathrm{~b}$ \\
Cultivar 1 & $50,67 \mathrm{a}$ & $150,11 \mathrm{a}$ & $8118 \mathrm{a}$ & $1,86 \mathrm{a}$ & $16,81 \mathrm{a}$ \\
Cultivar 2 & $63,00 \mathrm{a}$ & $12,56 \mathrm{~b}$ & $658 \mathrm{c}$ & $1,57 \mathrm{~b}$ & $0,99 \mathrm{c}$ \\
\hline
\end{tabular}

Means followed by the same letter in column do not differ statistically from themselves by Tukey test, at $5 \%$ probability.

Knowledge of the agronomic characters of quinoa allowed an estimation of the productivity of the crop to be made. Using the adjusted formula for estimated yield and the data in Table 1 , we calculated an estimated yield per plant of BRS Piabiru, cultivar 1 and cultivar 2 of $10.61 \mathrm{~g}, 14.15 \mathrm{~g}$, and $1.24 \mathrm{~g}$ respectively. The observed values for the cultivars were $10.58 \mathrm{~g}$ (BRS Piabiru), $16.81 \mathrm{~g}$ (cultivar 1), and 0.99 $\mathrm{g}$ (cultivar 2$)$. The chi-square test $(\mathrm{p}=0.75)$ found no significant difference between the calculated value and the observed value. It is worth noting that the cultivars studied are not commonly cultivated in the southern region of Brazil. Based on the variables corresponding to seed production (Table 1), it is possible to infer that cultivar 1 is the most adapted to the growing conditions of this region. Cultivar 2 showed lower seed production per plant, despite having a higher number of branches and reproductive structures.

Yield components are generally associated with a species' reproductive structures and seed mass. In the soybean crop, the number of pods, the number of grains per pod and the mass of a thousand seeds are used to estimate yield. In the corn crop, the number of cobs per plant, number of seeds per cob and mass of one thousand seeds are used. It is worth noting that these components are related to the area occupied by the plant (Bortolini et al., 2001; Navarro Junior \& Costa, 2002).

The yield components are determined by the cultivar but are influenced by the environmental conditions that occur during the crop season and by the cultural practices adopted (Bezerra et al., 2007; Kappes et al., 2008). Thus, knowledge of these characteristics in a new area of cultivation is of great importance for crop 
establishment. In the environmental conditions of southern Rio Grande do Sul State and traits genetics of genotypes influenced the number of branches was not a decisive factor for obtaining higher yields. In this region, seed production by branching positively influenced seed production. The mass of one thousand seeds can be influenced by several environmental factors, although Pandey and Torre (1973) stated that the mass of seeds is determined genetically. From the above, it is possible to infer that the cultivar most adapted to a given environment should produce seeds with the greatest mass.

The studied cultivars are annual plants that have

Table 2. Morphologic characters of stem from three quinoa cultivars grown in the southern Rio Grande do Sul.

\begin{tabular}{cccc}
\hline Characters & BRS Piabiru & Cultivar 1 & Cultivar 2 \\
\hline Habit & Indeterminate & Indeterminate & Indeterminate \\
Height & $135(67-177)$ & $157,8(134-178)$ & $123,4(39-148)$ \\
Consistency & Herbaceous & Herbaceous & Herbaceous \\
Shape & Cylindrical & Cylindrical & Cylindrical \\
Axil (striae) & Striae & Purple Axil & Striae \\
Branches & Yes (No) & Yes & Yes \\
Other notes & - & - & Purple axils \\
\hline
\end{tabular}

Table 3. Morphologic characters of leaves from three quinoa cultivars grown in the southern Rio Grande do Sul.

\begin{tabular}{cccc}
\hline Characters & BRS Piabiru & Cultivar 1 & Cultivar 2 \\
\hline Phylloxia & Spiral alternate & Spiral alternate & Spiral alternate \\
Petiole presence & Yes & Yes & Yes \\
Petiole length & $0,92(0,5-3)$ & $8,3(5-12)$ & $0,93(0,5-1)$ \\
Cuticular feature & Glabrous & No & Glabrous \\
Consistency & Chartaceous & Chartaceous & Chartaceous \\
Limbo shape & Ovate & Ovate & Ovate \\
Length & $5,81(4,6-7,9)$ & $5,08(4,4-6)$ & $4,85(3,5-5,5)$ \\
Width & $5,33(4,6-7,2)$ & $4,2(3,3-4,8)$ & $3,8(2,9-4,8)$ \\
Veins & Pinnate & Pinnate & Pinnate \\
Base & Truncate & Truncate & Truncate \\
Apex & Acute & Acute & Acute \\
Margin & Dentate & Dentate & Dentate \\
Note (n ${ }^{\circ}$ dents) & $22(12-28)$ & $6(3-10)$ & $4(2-6)$ \\
\hline
\end{tabular}

Plants of cultivar 1 were 1.34 to $1.78 \mathrm{~m}$ tall, with a branched, streaked stalk, with striations and purplish wings (Table 2, 3 and 4). The leaves had a toothed margin, with $3 \neg 10$ teeth (arranged in the lower half of the limbus), petiolate; the petiole of adult leaves was 5 to $12 \mathrm{~cm}$ long, and leaves were 4.4 to $6 \mathrm{~cm}$ long and in common an erect and cylindrical stem, simple leaves, with alternating spiral phyllotaxis, glabrous, chartaceous, stinging, truncated base, apiculate apex, toothed and petiolate margin. The flowers are gathered in dense panicles of glomeruli (axillary and a larger terminal), shortly pedicellate, greenish and chalice gamosepalous. There are five stamens, which are free, didymous, and inserted in the receptacle, an anther bithecous and longitudinal dehiscence. There are two filamentous stigmata. The ovary is superficial, glabrous, unilocular, tricarpellar and uniovular (Table 2, 3 and 4). 
margin; petioles were 0.5 to $3 \mathrm{~cm}$ long, leaves were 4.6 to $7.9 \mathrm{~cm}$ long and 4.6 to $7.2 \mathrm{~cm}$ wide, and flowers were $0.8-1.2 \mathrm{~mm}$ long, with a pedicel 0.4 to $1 \mathrm{~mm}$ long.

Plants of cultivar 2 were 0.39 to $1.48 \mathrm{~m}$ tall with a branched stem with streaks and purplish wings, and leaves with a toothed margin, showing from 2 to 6 teeth (arranged in the lower half of the limbus); the petiole of adult leaves was 0.5 to $1 \mathrm{~cm}$ long, the leaves were 3.5 to $5.5 \mathrm{~cm}$ long and 2.9 to $4.8 \mathrm{~cm}$ wide and the flowers were 0.8 to $1.2 \mathrm{~mm}$ long with a pedicel of length 0.1 to $2.5 \mathrm{~mm}$ (Tables 2, 3 and 4).

There was a difference between cultivars in number of teeth in the adult leaves. BRS Piabiru had 12 to 28 teeth, cultivar 1 had three to ten teeth while cultivar 2 had two to six teeth per adult leaf (Figure 1). The number of teeth along the margins of adult leaves can thus be used to differentiate BRS Piabiru from the other cultivars.

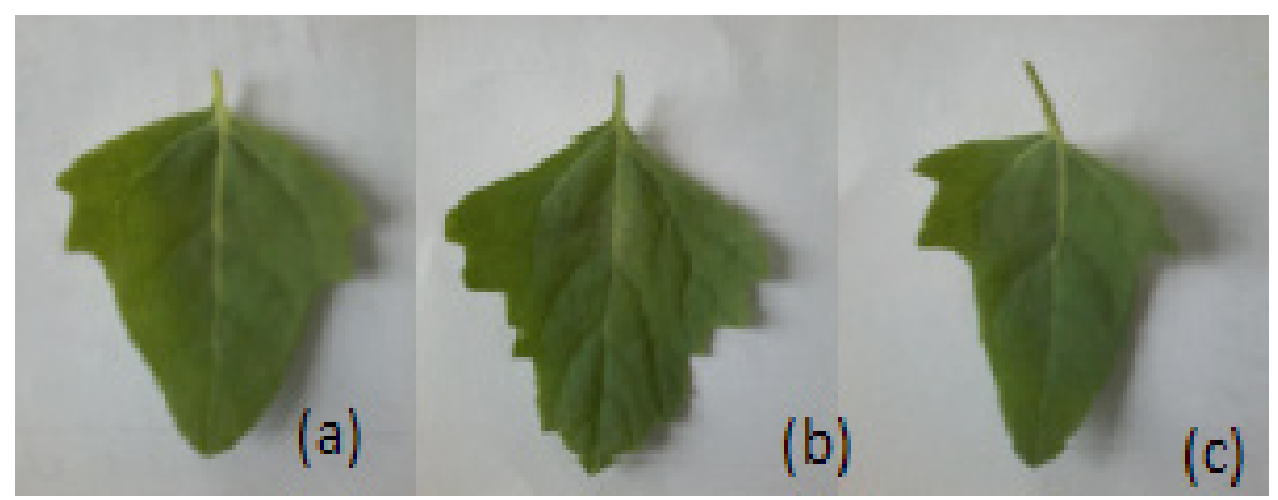

Figure 1. Adult leaves of quinoa, Cultivar 1(a), BRS Piabiru (b) and Cultivar 2(c).

In countries where quinoa production is to distinguish cultivars (FAO, 2015). In these regions, traditional, cultivars are described by evaluating the striae and wings in the leaf axils are also used in the specific morphological characteristics, and the number characterization of cultivars.

of teeth on the leaf is one of the characteristics used Stretch marks were observed on the stem in all Table 4. Morphologic characters of inflorescence from three quinoa cultivars grown in the southern Rio Grande do Sul

\begin{tabular}{|c|c|c|c|}
\hline Characters & BRS Piabiru & Cultivar 1 & Cultivar 2 \\
\hline Inflorescence & Lax & Lax & Lax \\
\hline Flower length & $1,04(0,8-1,2)$ & 1 & $0,93(0,7-1,2)$ \\
\hline Pedicel presence & Subsessels & Subsessels & Subsessels \\
\hline Pedicel length & $0,58(0,4-1)$ & $0,6(0,5-1)$ & $2,05(0-2,5)$ \\
\hline Color & Greenish & Greenish & Greenish \\
\hline $\mathrm{N}^{\circ}$ of sepals calyx & 5 & $5(6-7)$ & 5 \\
\hline Calyx union & United sepals & United sepals & United sepals \\
\hline Notes & 1 pediculate flower & 1 pediculate flower & 1 pediculate flower \\
\hline $\mathrm{N}^{\circ}$ stamens & 5 & 5 & 5 \\
\hline Size of stamens & Isodynamic & Isodynamic & Isodynamic \\
\hline Stamens $n^{\circ}$ of teak & 2 & Biteak & 2 \\
\hline Stamens dehiscence & Rimose & Rimose & Rimose \\
\hline Stamen insertion & Receptacle & Receptacle & Receptacle \\
\hline $\mathrm{N}^{\circ}$ stigmas & 2 & 2 & 2 \\
\hline Ovary position & Superior & Superior & Superior \\
\hline Presence of hairiness in ovary & Glabrous & Glabrous & Glabrous \\
\hline $\mathrm{N}^{\circ}$ of locus & 1 & 1 & 1 \\
\hline $\mathrm{N}^{\circ}$ of carpel & 1 & 1 & 1 \\
\hline $\mathrm{N}^{\circ}$ of ovule per locus & 1 & 1 & 1 \\
\hline
\end{tabular}


cultivars in southern Brazil. The presence of wings was verified only in BRS Piabiru (Table 2). However, wing and streak pigmentation were not present in all plants of the same cultivar, that is, there was high heterogeneity within cultivars for this characteristic. The mean height of BRS Piabiru plants was $1.35 \mathrm{~m}$ (Table 2). However, Spehar and Souza (1993) reported a mean height of $1.90 \mathrm{~m}$ for the same cultivar. This difference could be attributed to the cultivation environment since the experiment carried out by these authors was located in the central region of Brazil, where edaphoclimatic conditions differ from those of the current study. Thus, in the southern conditions of Rio Grande do Sul, BRS Piabiru plants tend to be of smaller stature compared to plants cultivated at lower latitudes. These results are consistent with those of Vasconcelos et al. (2012), who reported that the occurrence of low temperatures during the vegetative stage determines the formation of quinoa plants of shorter stature.

Quinoa cultivars cultivated in the Andean Region can be classified as Highlands Quinoa, Inter-Andean valley Quinoa, Salares Quinoa, Yungas Quinoa, and Coastal/Lowlands Quinoa. These differ in cycle and height of the plant, thus demonstrating the genetic variability present in the crop (Pando \& Barra, 2012). Thus, the identification of different cultivars is of considerable importance within fields dedicated to seed production.

Quinoa is allotetraploid ( $2 n=4 x=36)$, exhibiting disomic genetic inheritance for most qualitative characteristics (Ward, 2000). This condition hinders gain in selection in segregating populations, making the selective process increasingly complicated, due to the lower chance of genetic gain in comparison with a diploid organism (Oliveira et al., 2013). In seed production, it is essential to be aware of the existence of morphological differences between cultivars of the same species. In Brazil, the identification of cultivars is usually carried out using morphological descriptors (Bonow et al., 2007). This description helps to identify the genetic and varietal mixture, and the distinction between cultivars allows the separation of undesirable genetic materials within the field and in some cases indicates the need for disposal.

\section{CONCLUSION}

For the culture of quinoa it is possible to use morphological genetic markers with the conformations of the teeth or lobes of the leaf and its shade, in contrast, the length of the petioles are not good markers due to low genetic variability. The genetic and phenotypic variability and trends expressed in this study allow further studies of genetic improvement, seed technology and agronomic positioning for quinoa to be carried out for other regions of Brazil.

\section{REFERENCES}

BARROSO, G.M.; MORIM, M.P.; PEIXOTO. A.L.; ICHASO, C.L.F. 1999. Frutos e sementes: morfologia aplicada à sistemática de dicotiledôneas. UFV. 443p.

BEZERRA, A. P. A.; PITOMBEIRA, J.B.; TÁVORA, J.A.F.; VIDAL NETO, F.C. 2007. Rendimento, componentes da produção e uso eficiente da terra nos consórcios sorgo x feijão-de-corda e sorgo x milho. Revista Ciência Agronômica, 38(1): 104-108.

BIOVERSITY INTERNATIONAL, FAO, PROINPA, INIAF y FIDA. 2013. Descriptores para quinua(Chenopodium quinoa Willd.) y sus parientes silvestres. Bioversity International, Roma, Italia; Organización de las Naciones Unidas para la Agricultura y la alimentación, Roma, Italia; Fundación PROINPA, La Paz, Bolivia; Instituto Nacional de Innovación Agropecuaria y Forestal, La Paz, Bolivia; Fondo Internacional de Desarrollo Agrícola, Roma, Italia. 54p.

BONOW, S.; VON PINHO, E.V.; SOARES, A.A.; SIÉCOLA JÚNIOR, S. 2007. Morphological characteristics of rice cultivars; application for variety purity certification. Ciência agrotécnica, Lavras, v. 31, n. 3, p. 619-627.

BORTOLINI, C. G.; SILVA, P. R. F; ARGENTA, G.; FORSTHOFER, E. L. 2001. Rendimento de grãos de milho cultivado após aveia-preta em resposta a adubação nitrogenada e regime hídrico. Pesquisa Agropecuária Brasileira, v. 36, n. 9, p. 1101-1106. 
BURKART, A. Leguminosae. In: BURKART, A.; BURKART, N.S.T.; BACIGALUPO, N. M. (6ed.) Flora Ilustrada de Entre Ríos (Argentina). Buenos Aires, p. 442-743, 1987.

FAO. Distribuición y produción. Dísponivel em: http://www.fao.org/quinoa-2013/what-is-quinoa/ distribution-and-production/es/ acesso em: 28 jan. de 2018.

FUENTES-BAZAN, S.; UOTILA, P.; BORSCH, T. 2012. Anovel phylogeny-based generic classification for Chenopodium sensu lato, and a tribal rearrangement of Chenopodioideae (Chenopodiaceae). Willdenowia, v. 42, p. 5-24.

JUDD, W.S., CAMPBELL, C.S., KELLOGG, E.A., STEVENS, P.F.; DONOGHUE, M.J. 2009. Sistemática Vegetal: Um Enfoque Filogen Ético (3ed.). Porto Alegre: Artmed, 612p.

KAPPES, C.; WRUCK, F. J.; CARVALHO, M. A. C.; YAMASHITA, O. M. 2008. Feijão comum: características morfoagronômicas de cultivares. In: Congresso nacional de pesquisa de feijão. Campinas, Brasil, p. 506-509.

NAVARRO JUNIOR, H. M.; COSTA, J. A. 2002. Contribuição relativa dos componentes do rendimento para produção de grãos em soja. Pesquisa agropecuaria brasileira, v. 37, n. 3, p. 269-274.

OLIVEIRA, G.A.; VASCONCELOS, E.S.; ACHRE, D. 2013. Divergência genética entre genótipos de quinoa quanto a crescimento morfológico e caracteres da panícula. Scientia Agraria Paranaensis, v. 12, n. 10, p. 434-439.

PANDEY, J.P.; TORRIE, J.H. 1973. Path coefficient analysis of seeds yeald components in soybean (Glycine $\max$. Crop science, v. 13, n. 5, p. 505-507.

PANDO, L.R.G.; BARRA, A.L.E. 2012. Catalogo del Banco de Germoplasma de Quinua (Chenopodium quinoa).(2 ed). Lima: INCAGRO. 181p.
SINGH, S. P. 2001. Broadening the genetic base of common bean cultivars: a review. Crop Science, v. 41, n. 6 , p. $1659-1675$.

SOUZA, V.C.; LORENZI, H. 2012. Botânica Sistemática: guia ilustrado para identificaçáo das famílias de Fanerógamas nativas e exóticas no Brasil, baseado em APG III. 3ed. Instituto Plantarum, Nova Odessa, São Paulo, 768p.

SPEHAR, C. R.; SANTOS, R. L. B. 2002. Quinoa (Chenopodium quinoa Willd) BRS Piabiru: Alternativa para diversificar os sistemas de produção de grãos. Pesquisa Agropecuária Brasileira, v. 37, n. 6, p. 889-893.

SPEHAR, C.R. 2006. Adaptação da quinoa (Chenopodium quinoa Willd.) para incrementar a diversidade agrícola e alimentar no Brasil. Cadernos de Ciência \& Tecnologia, v. 23, n. 1, p.41-62.

SPEHAR, C.R.; SOUZA, P.I.M. 1993. Adaptação quinoa (Chenopodium quinoa Willd.) ao cultivo nos cerrados do Planalto Central: resultados preliminares. Pesquisa Agropecuária Brasileira, v. 28, n. 5, p. 635639.

THOMAS, A. L.; COSTA, J. A. 2010. Desenvolvimento da planta de soja e potencial de rendimento de grãos. In: THOMAS, A. L., COSTA, J. A. Soja: manejo para alta produtividade de gráos. Porto Alegre: Evangraf.

WARD, S.M. .2000. Allotetraploid segregation for single-gene morphological characters in quinoa (Chenopodium quinoa Willd). Euphytica, v. 116, p. 11-16.

VASCONCELOS, F. S.; VASCONCELOS, E. S.; BALAN, M.G.; SILVERIO, L. 2012. Desenvolvimento e produtividade de quinoa semeada em diferentes datas no período safrinha. Revista Ciência Agronômica. v. 43, n. 3, p. 510-515. 
ZILIO, M.; COELHO, C.M. M.; SOUZA, C. A.; SANTOS, J. C. P.; MIQUELLUTI, D. J. 2011. Contribuição dos componentes de rendimento na produtividade de cultivaress crioulos de feijão (Phaseolus vulgaris L.). Revista Ciência Agronômica, v. 42 , n. 2 , p. $429-438$. 